\title{
Urine $\mathrm{pH}$ as an index for calculating the amount of bicarbonate for treatment of acidotic calves
}

\section{Tatiana Lubetskaya and D. Melnichuk}

Agricultural University of Ukraine,

Geroev Oborony 15, 25204l Kiev, Ukraine

(Received 15 October 1998; accepted 19 March 1999)

\section{ABSTRACT}

It was shown that acute metabolic acidosis is one of the significant signs of diarrhoea in new-born calves. A rectilinear dependence was observed between urine $\mathrm{pH}$ indices and parameters of base excess of the acid-base balance in their blood. A method of correcting the different stages of metabolic acidosis in calves with diarrhoea by sodium bicarbonate, based on urine $\mathrm{pH}$ values, is proposed.

KEY WORDS: calves, diarrhoea, metabolic acidosis, urine-pH, sodium bicarbonate

\section{INTRODUCTION}

Acid-base balance plays an exceptionally important role in the regulation of metabolic processes (Guliy, 1978). More and more new biological features have been shown to be sensitive to changes in the basic parameters of acid-base balance, particularly tissue $\mathrm{pH}$, carbon dioxide pressure $\left(\mathrm{pCO}_{2}\right)$, bicarbonate level $\left(\mathrm{HCO}_{3}\right)$ in the tissues.

There is a connection between the changes in acid-base balance both in acidosis and alkalosis and metabolic disturbances that affect physiological function and overall condition of an organism (Melnichuk, 1989). Investigations of acid-base balance indicate the need to correct metabolic acidosis in various pathological states.

Decompensatory metabolic acidosis was observed in sick calves with diarrhoea caused by E. coli, Salmonella, rota-, coronavirus and chlamidia (Tennant et al., 
1972; Szenci, 1985; Sadiek et al., 1995). The sick calves do not die of bacterial infection, they die of dehydration, acidosis and shock (Torres, 1987). Therefore, it is necessary to check the acid-base balance in new-born calves and to correct it if there is acute metabolic acidosis (Michna et al., 1996; Geishauser et.al., 1997; Hartmann et al., 1997). We studied the features of development of metabolic acidosis in diarrhoeic calves and the relationship between their urine $\mathrm{pH}$ indices and the main blood parameters of acid-base balance. These results were used to create a method of indirect determination of base excess in the blood of the new-born calves and for the correction of different levels of metabolic acidosis.

\section{MATERIAL AND METHODS}

The first step in our investigation was to analyze the acid-base balance in the blood of sick $(n=15)$ and healthy $(n=8)$ new-born calves at the age of 2 to 6 days. Acid-base balance parameters in the blood of sick new-born calves were studied in the following states: before and during the first signs of diarrhoea, moderate diarrhoea, and severe diarrhoea. Indices of $\mathrm{pH}$, carbon dioxide partial pressure $\left(\mathrm{pCO}_{2}\right)$, current bicarbonate $\left(\mathrm{HCO}_{3}\right)$, base excess $(\mathrm{BE})$ and total $\mathrm{CO}_{2}$ in blood were determined using a type OP. 215 (Rodelkis) $\mathrm{pH}$-blood-gas-analyzer.

In the second series of investigations, 45 clinically healthy and 42 diarrhoeic calves were used to investigate the correlation between $\mathrm{pH}$ values of urine with blood acid-base indices. Fifty-seven calves, 42 sick and 15 healthy, 2- to 10 -dayold, were used in this study. Linear regression was used to determine the correlation between these indices (Polyakov, 1982). Blood and urine samples were obtained early in the morning. The $\mathrm{pH}$ of urine samples was determined immediately. The blood samples were obtained under aerobic conditions, transported at $0-4^{\circ} \mathrm{C}$ and measured within $3 \mathrm{~h}$.

Under experimental conditions we calculated the quantity of sodium bicarbonate for 1 unit base deficit and $1 \mathrm{~kg}$ body weight of diarrhoeic calves; the bicarbonate was given orally in the amount needed for correction of acid-base disturbances.

In the next series, 22 calves (group 1) and 18 calves (group 2) 4 to 6 days old with moderate or severe diarrhoea were treated with oral rehydration solution containing $\mathrm{NaCl}, \mathrm{NaHCO}_{3}$ and glucose. The solution (1-1.5 l) was given $30 \mathrm{~min}$ before feeding 3 times daily. Two to three feedings of milk were withheld when we observed the first symptoms of diarrhoea. The groups differed in the quantity of sodium bicarbonate in the rehydration solution. The first group of calves received bicarbonate according their urine $\mathrm{pH}$ values. The 10 sick calves were given 5.0-3.0 g sodium bicarbonate 3 times daily with rehydration solution when urine $\mathrm{pH}$ values were $6.0-6.4$. The quantity of $\mathrm{NaHCO}_{3}$ was calculated using a nomogram (Figure 4 ) when urine $\mathrm{pH}$ values $(12$ calves) dropped below 6.0. The calves 
of the second group with moderate ( 8 calves) and severe diarrhoea (10 calves) were given $5.0 \mathrm{~g}$ sodium bicarbonate with rehydration solution under the same conditions.

\section{RESULTS}

Aspects of acute acid-base disturbances in the calves with diarrhoea are shown in Figure 1.

According to our study, the $\mathrm{pH}$ and bicarbonate levels in calf blood were lower before diarrhoea compared to those in healthy calves, but the blood level of $\mathrm{pCO}_{2}$ was significantly higher $(\mathrm{P}<0.05)$ in sick animals. This is the result of respiratorymetabolic acidosis in their bodies during that period. Blood $\mathrm{pH}$ and bicarbonate concentrations in the sick calves during the first symptoms of diarrhoea were significantly lower $(\mathrm{P}<0.05)$ than in healthy ones and in calves before diarrhoea. Acute acid-base disturbances were found in the sick calves with severe diarrhoea. The blood BE index in these animals was reduced sharply (below $17 \mathrm{mmol} / \mathrm{l}^{-1}$ ).

The urine $\mathrm{pH}$ values in clinically healthy calves ranged from 6.2 to 7.3. The urine $\mathrm{pH}$ indices of diarrhoeic calves with acute metabolic acidosis were decreased.
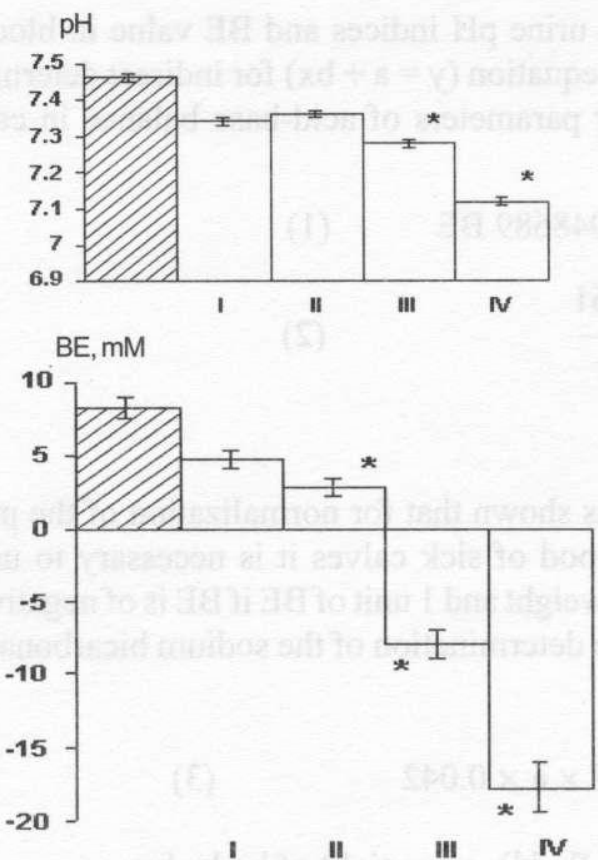

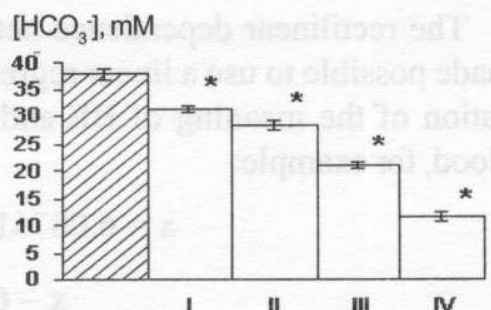

I - before diarrhoea

II - the first symptoms of diarrhoea

III - moderate diarrhoea

IV - severe diarrhoea

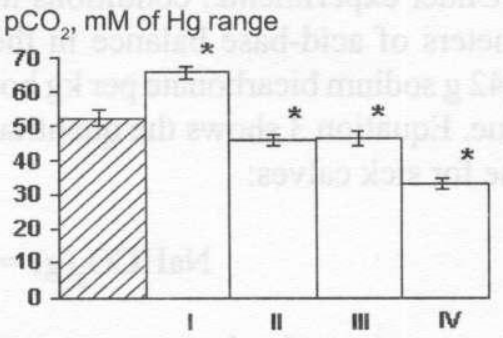

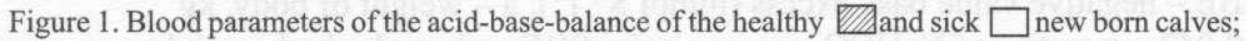

* significant differences $(\mathrm{P}<0.05)$ 
In calves during the first symptoms of diarrhoea and with mild diarrhoea, urine $\mathrm{pH}$ values were from 6.0 to 6.4. In moderate and severe diarrhoea these values dropped below 6.0 .

The correlation coefficient between urine $\mathrm{pH}$ indices and parameters of acidbase balance in calf blood was significant $(r=0.8850, P \leq 0.001)$. The correlation coefficient was also significant between indices of urine $\mathrm{pH}$ and blood $\mathrm{pH}$ $(r=0.7667, P \leq 0.001)$ and $B E(r=0.7247, P \leq 0.001 ;$ Figure 2$)$.

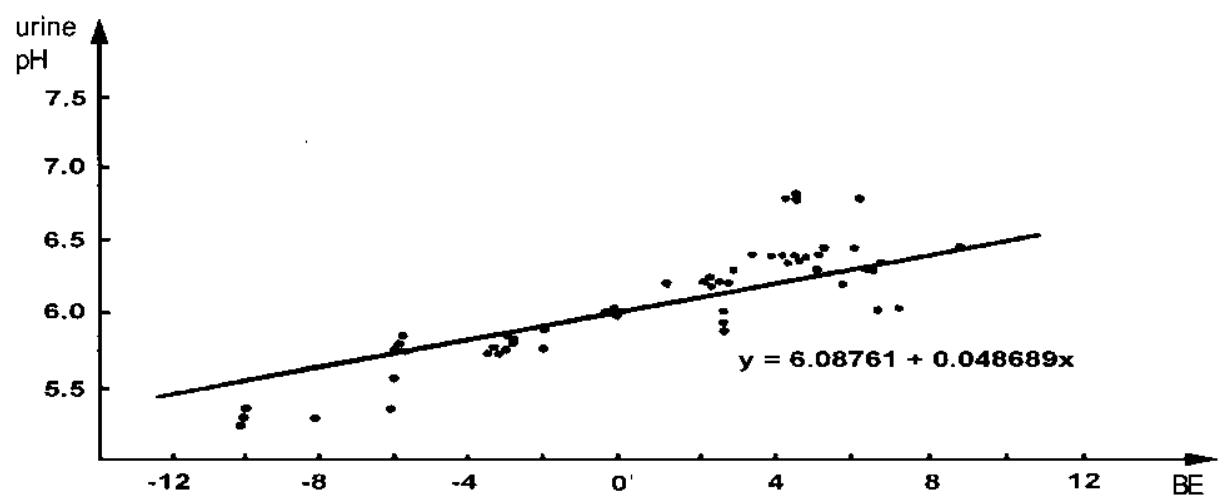

Figure 2. The relationship between urine $\mathrm{pH}$ indices and base excess of calves blood

The rectilinear dependence between urine $\mathrm{pH}$ indices and $\mathrm{BE}$ value in blood made possible to use a linear regression equation $(y=a+b x)$ for indirect determination of the meaning of $\mathrm{BE}$ and other parameters of acid-base balance in calf blood, for example:

$$
\begin{aligned}
& \mathrm{x}=6.08761+0.048689 \mathrm{BE} \\
& \mathrm{BE}=\frac{\mathrm{x}-6.08761}{0.048689}
\end{aligned}
$$

$\mathrm{x}$ - urine $\mathrm{pH}$ of calf.

Under experimental conditions it was shown that for normalization of the parameters of acid-base balance in the blood of sick calves it is necessary to use $0.042 \mathrm{~g}$ sodium bicarbonate per $\mathrm{kg}$ body weight and 1 unit of $\mathrm{BE}$ if $\mathrm{BE}$ is of negative value. Equation 3 shows the quantitative determination of the sodium bicarbonate dose for sick calves:

$$
\mathrm{NaHCO}_{3}(\mathrm{~g})=\mathrm{BE} \times \mathrm{a} \times 0.042
$$

$\mathrm{BE}$ - negative value base excess $\left(\mathrm{mmol} \mathrm{S} \cdot \mathrm{l}^{-1}\right)$, a - weight of body, $\mathrm{kg}$ 0.042 - quantity of $\mathrm{NaHCO}_{3}$ per one unit of $\mathrm{BE}$ and one $\mathrm{kg}$ body weight. 
Using equation 2, the dose of sodium bicarbonate may be determined according to the next equation:

$$
\mathrm{NaCO}_{3}(g)=\frac{\mathrm{x}-6.0876}{0.48689} \times \mathrm{a} \times 0.42
$$

$\mathrm{x}$ - urine $\mathrm{pH}, \mathrm{a}$ - body weight, $\mathrm{kg}$.

The results of correction of metabolic acidosis according to equation 4 are shown in Figure 3. The different doses of sodium bicarbonate normalized the parameters of acid-base balance in the blood of sick calves.

The aim of our study was to simplify the calculation of the quantity of sodium bicarbonate for correction of metabolic acidosis in calves, and we propose the following nomogram (Figure 4).
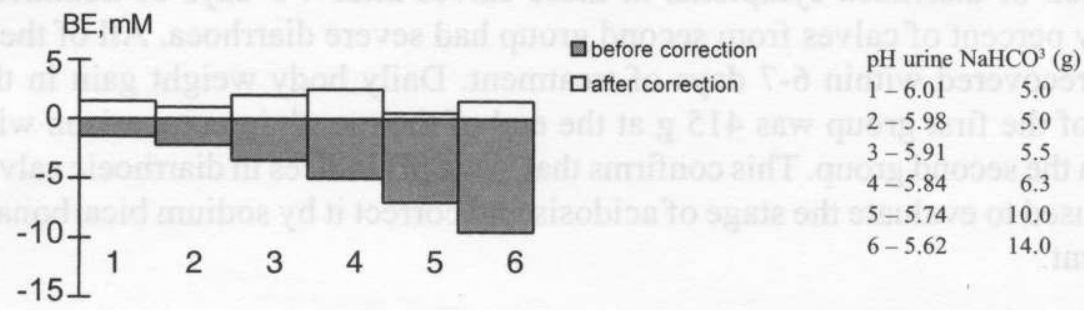

Figure 3. Correction of the metabolic acidosis in the calves by bicarbonate according of the urine $\mathrm{pH}$ (formula 3)

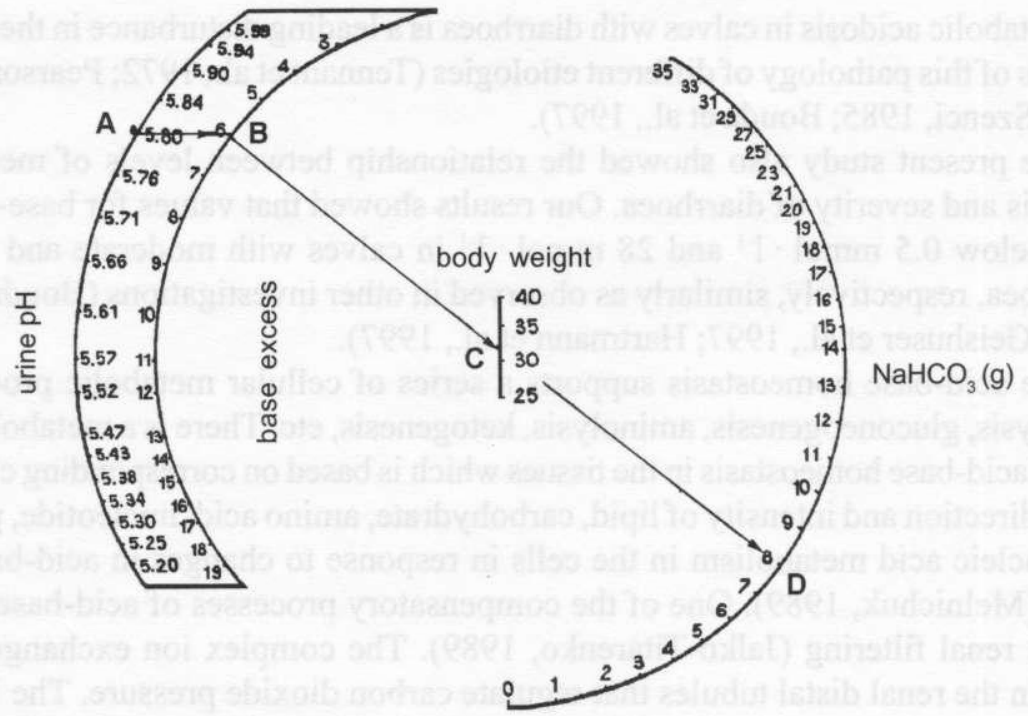

Figure 4. Nomogram for the quantitative determination of the $\mathrm{NaHCO}_{3}$ for diarrhoeic calves 
According to the nomogram, first we need to accurately determine the calf urine $\mathrm{pH}$ index early in the morning before the first feeding (A), then we need to find the value of $\mathrm{BE}$ on the nomogram (B) and using the body weight of the calf (C) to determine the sodium bicarbonate quantity (D). This quantity of sodium bicarbonate can be given to diarrhoeic calves in oral rehydration solution and as $5-10 \%$ solutions $30 \mathrm{~min}$ period before feeding 3 times per day.

During the correction of metabolic acidosis in diarrhoeic calves with allowance for their urine $\mathrm{pH}, 70 \%$ calves had light short-term diarrhoea in first three days of life without clinical complications. Diarrhoea of moderate to severe intensity was observed in all calves 5 to 7 days old.

The bicarbonate therapy was effective when it was based on the calves' urine $\mathrm{pH}$ indices. All of the calves in the first group had good standing ability and suckling reflex. Their urine $\mathrm{pH}$ values were at a level of 6.4-7.5. We observed resolution of diarrhoea symptoms in these calves after 4-5 days of treatment. Seventy percent of calves from second group had severe diarrhoea. All of these calves recovered within 6-7 days of treatment. Daily body weight gain in the calves of the first group was $415 \mathrm{~g}$ at the end of the month in comparison with $315 \mathrm{~g}$ in the second group. This confirms that urine $\mathrm{pH}$ indices in diarrhoeic calves can be used to evaluate the stage of acidosis and correct it by sodium bicarbonate treatment.

\section{DISCUSSION}

Metabolic acidosis in calves with diarrhoea is a leading disturbance in the pathogenesis of this pathology of different etiologies (Tennant et al., 1972; Pearson et al., 1983; Szenci, 1985; Bouda et al., 1997).

The present study also showed the relationship between levels of metabolic acidosis and severity of diarrhoea. Our results showed that values for base-excess drop below $0.5 \mathrm{mmol} \cdot \mathrm{1}^{-1}$ and $28 \mathrm{mmol} \cdot 1^{-1}$ in calves with moderate and severe diarrhoea, respectively, similarly as observed in other investigations (Bouda et al., 1997; Geishuser et al., 1997; Hartmann et al., 1997).

The acid-base homeostasis supports a series of cellular metabolic processes: glycolysis, gluconeogenesis, aminolysis, ketogenesis, etc. There is a metabolic system of acid-base homeostasis in the tissues which is based on corresponding changes in the direction and intensity of lipid, carbohydrate, amino acid, nucleotide, protein and nucleic acid metabolism in the cells in response to changes in acid-base balance (Melnichuk, 1989). One of the compensatory processes of acid-base disorders is renal filtering (Jalko-Titarenko, 1989). The complex ion exchange takes place in the renal distal tubules that regulate carbon dioxide pressure. The ion exchange supports normal levels of bicarbonate in the blood. Hydrogen ions are inten- 
sively excreted in the process of bicarbonate restoring and sodium reabsorption. This mechanism determines urine $\mathrm{pH}$ changes.

We agree with other investigators (Schlerka G. et al., 1995, 1996) that the measurement of calf urine $\mathrm{pH}$ can not be a direct method of determining blood parameters of acid-base balance in calves. Urine $\mathrm{pH}$ of calves during the first symptoms of diarrhoea and with moderate diarrhoea can be the same as in healthy calves. But, in our opinion, urine $\mathrm{pH}$ values of 6.0-6.4 indicate that the kidney is intensively eliminating acid equivalents even in healthy calves. These $\mathrm{pH}$ values can coincide with activation of buffer systems and metabolic compensatory processes that support acid-base homeostasis in the tissues of sick calves for some time. This may negatively influence the correlation between $\mathrm{pH}$ values of urine and the blood parameters of acid-base balance at this stage. It is necessary to recognize that at this state, the base reserve in these calves' tissues is decreasing. Urine $\mathrm{pH}$ values below 6.0 indicate acute metabolic acidosis in calves, requiring appropriate intervention.

As the regression analysis has shown, the base excess indices of blood and urine $\mathrm{pH}$ were correlated. This inspired us to propose the method of correcting the different stages of metabolic acidosis in calves with diarrhoea. The diagnostics of acid-base disturbances in animals remains a problem in veterinary practice, and sometimes reduces therapy efficacy. With the proposed nomogram we have tried to help veterinarians in correcting the features of metabolic acidosis in diarrhoeic calves and have demonstrated that differentiated correction is possible.

\section{REFERENCES}

Bouda J., Doubek J., Medina C.M., Paasch M.L., Candanosa A.E., Drovak R., Soska V., 1997. Pathophysiology of severe diarrhoea and suggested intravenous fluid therapy in calves of different ages under field conditions. Acta Vet. Brno 66, 87-94

Geishauser T., Tunker B., 1997. Metabolic acidosis in diarrhoeic neonatal calves-treatment using isomolar sodium bicarbonate solution. Prakt.Tierärzt. 78, 595-600

Guliy M.F., Melnichuk D.O., 1978. The Role of $\mathrm{CO}_{2}$ in the Regulation of Metabolism in the Heterotrophogenic Organism (in Russian). Kiev. Naukova Dumka, pp. 242

Hartmann H., Berhtold J., Hofmann W., 1997. Pathophysiological aspects of acidosis in diarrhoeic calves. Tierarztl. Umsch. 52, 568-574

Jalko-Titarenko B.F., 1989. Water and Electrolyte Metabolism under Normal Condition and Pathology (in Russian). Kiev, pp. 200

Melnichuk D.O., 1989. Metabolic system of acid-base homeostasis in animals and human organism. Ukr. Biochem. J. 61, 3-21

Michna A., Bartko P., Bires J., Lehocky J., Reichel P., 1996. Metabolic acidosis in calves with diarrhoea and its treatment with sodium bicarbonate. Vet. Med. 41, 305-310

Pearson V.R., Logon, E.F., 1983. The pathology of neonatal enteritis in calves with observation on E.coli, rotavirus and cryptosporidium. Ann. Rech. Vet. 14, 422-425 
Polyakov A.V., 1982. The Step Rectilinear Analysis (in Russian). Kiev, pp. 21

Sadiek A., Shlerka G., 1995. Studies on rehydration therapy in diarrheic milk-fed calves. Proceedings of the 3rd Scientific Congress of the Egyptian Society for Cattle Diseases. Assiut University, Egypt, pp. 47-56

Shlerka G., Baumgartner W., 1995. Correlation between urine $\mathrm{pH}$ and blood $\mathrm{pH}$ values in neonatal diarrhoeic calves. Proceedings of the 3rd Scientific Congress of the Egyptian Society for Cattle Diseases. Assiut University, Egypt, pp. 164-168

Shlerka G., Baumgartner W., Wehrle A., 1996. Value of urinary pH for interpreting acidaemia in unweaned calves with diarrhoca. Tierarztl. Umsch. 51, 96-99

Szenci O., 1985. Role of acid-base disturbances in prenatal mortality of calves. Acta. Vet. Hung. 33, 205-220

Tennant B., Harrold D., Reina-Guerra M., 1972. Physiologic and metabolic factors in the pathogenesis of neonatal enteric infection in calves. J. Amer. Vet. Med. Assoc. 161, 993-1007

Torres O., Gonzales J., Gonzales M., 1987. Zum Einfluss der Fütterung hochtragendes Kuhe auf ihren Saure-Basen-Status auf den Gesundheitszustand post partum sowie auf die Vitalität und Gesundheit der Neugeborenen Kalber. Mn. Vet. Med. 42, 130-132

\section{STRESZCZENIE}

pH moczu jako współczynnik do obliczania dawek kwaśnego węglanu w leczeniu acidozy u cieląt

Wykazano, że ostra acidoza metaboliczna jest ważną przyczyną powstawania biegunki u nowonarodzonych cieląt. Stwierdzono prostą zależność miedzy pH moczu a wartością równowagi kwasowo-zasadowej we krwi cieląt. Zaproponowano metodę leczenia cieląt przy różnym stopniu nasilenia acidozy metabolicznej z objawami biegunek poprzez podawanie im odpowiedniej ilości kwaśnego węglanu, obliczanej w prosty sposób przy zastosowaniu opracowanego nomogramu. 